\title{
The Daily Practice of Pancreatic Enzyme Replacement Therapy After Pancreatic Surgery: a Northern European Survey
}

\author{
Enzyme Replacement After Surgery
}

\author{
Edmée C. M. Sikkens • Djuna L. Cahen • \\ Casper van Eijck $\cdot$ Ernst J. Kuipers $\cdot$ Marco J. Bruno
}

Received: 1 March 2012 / Accepted: 30 May 2012 /Published online: 19 June 2012

(C) 2012 The Author(s). This article is published with open access at Springerlink.com

\begin{abstract}
Introduction After pancreatic surgery, up to $80 \%$ of patients will develop exocrine insufficiency. For enzyme supplementation to be effective, prescribing an adequate dose of pancreatic enzymes is mandatory but challenging because the required dose varies. Data on the practice of enzyme replacement therapy after surgery are lacking, and therefore, we conducted this analysis.

Methods An anonymous survey was distributed to members of the Dutch and German patient associations for pancreatic disorders. The target population consisted of patients with chronic pancreatitis or pancreatic cancer who had undergone pancreatic surgery and were using enzymes to treat exocrine insufficiency. Results were compared to a similar group of non-operated patients.

Results Ninety-one cases were analyzed ( $84 \%$ underwent a resection procedure). The median daily enzyme dose was 6 , and $25 \%$ took three or less capsules. Despite treatment, $68 \%$ of patients reported steatorrhea-related symptoms, $48 \%$ adhered to a non-indicated dietary fat restriction, and only $33 \%$ had visited a dietician. The outcome was equally poor for the 91 nonoperated patients.

Conclusion Most patients suffering from exocrine insufficiency after pancreatic surgery are undertreated. To improve efficacy, physicians should be more focused on treating exocrine insufficiency and educate patients to adjust the dose according to symptoms and their diet.
\end{abstract}

Keywords Chronic pancreatitis $\cdot$ Pancreatic cancer .

Exocrine pancreatic insufficiency $\cdot$ Pancreatic surgery

Pancreatic enzyme replacement

\section{Introduction}

In exocrine insufficiency, the pancreas is unable to deliver sufficient quantities of digestive enzymes to the small

E. C. M. Sikkens $(\bowtie) \cdot$ D. L. Cahen · E. J. Kuipers · M. J. Bruno Department of Gastroenterology and Hepatology,

Erasmus University Medical Center,

PO Box 2040, 3015 CE Rotterdam, The Netherlands

e-mail: e.sikkens@erasmusmc.nl

C. van Eijck

Department of Surgery, Erasmus University Medical Center,

Rotterdam, The Netherlands intestine. Because of the large residual capacity of the pancreas, exocrine insufficiency becomes clinically apparent only when $90 \%$ of the function is lost. ${ }^{1,2}$ After pancreatic surgery, the exocrine function is determined by the underlying pancreatic disease and the chosen surgical procedure (depending on the extent of the resection and the restoration of gastrointestinal tract continuity). ${ }^{3,4}$ Postoperatively, exocrine insufficiency is observed in 65 to $80 \%$ of the patients with chronic pancreatitis. ${ }^{5,6}$ In patients with pancreatic cancer, exocrine insufficiency is found in 68 to $92 \%$ before surgery and in $80 \%$ after surgery. $^{7}$

Exocrine insufficiency leads to malabsorption, which causes steatorrhea, weight loss, and malnutrition. ${ }^{8-11}$ It is associated with deficiencies of the fat-soluble vitamins (vitamin A, D, E, and K), magnesium, calcium, and essential fatty and amino acids. ${ }^{12-15}$ To reduce morbidity and mortality, patients should be treated with a sufficient dose of pancreatic enzymes. ${ }^{16-19}$ In clinical practice, enzyme replacement therapy proves challenging because the optimal enzyme dose is 
highly variable, depending on the remaining pancreatic function, the postsurgical anatomy, and the dietary fat content. Unfortunately, physicians are often not well informed about the need to supplement exocrine insufficiency in a flexible and patient-tailored manner. In addition, exocrine insufficiency is frequently overlooked because the primary attention is directed towards treatment of the underlying disease. This may be especially true for surgeons who are confronted with a patient with pancreatic cancer because their main concern is to explore curative options.

Remarkably, data on the clinical practice of enzyme replacement therapy in surgically treated patients are lacking. Therefore, this survey was conducted to evaluate the daily practice of enzyme replacement therapy in postoperative patients.

\section{Methods}

This prospective, cross-sectional study was approved by the Medical Ethics Committee of the Erasmus University Medical Center in Rotterdam. In 2010, an anonymous survey was distributed among the members of the Dutch and German patient associations for pancreatic disorders. The target population consisted of surgically treated patients with chronic pancreatitis or pancreatic cancer who were using enzymes to treat exocrine insufficiency. We also assessed the responding members who fulfilled the criteria of the target population, but had not been operated upon.

The survey was distributed by mail and had to be returned within 3 months. After 4 weeks, a reminder was sent out to the members that had not responded. The survey contained free field and multiple-choice questions and took about $10 \mathrm{~min}$ to complete. The items evaluated in the survey were the daily enzyme dose (recalculated as the number of capsules containing 25,000 FIP (Fidiration Internationale Pharmaceutique) units of lipase), the timing of enzyme ingestion, the presence of steatorrhea-related symptoms (bloating; abdominal cramps; bulky, sticky, and fatty stools), referral to a dietician, and restrictions in fat intake (either recommended by a physician or dietician, or self-imposed).

Statistical analyses were conducted using SPSS 17.0. Results were expressed as medians and percentiles using the appropriate $t$ tests or nonparametric tests for continuous variables. For categorical data, the $X^{2}$ test was used.

\section{Results}

Two hundred and sixty-five members responded to the survey, of which $182(69 \%)$ had chronic pancreatitis or pancreatic cancer and were using pancreatic enzymes for exocrine insufficiency. The baseline characteristics of these 182 patients are described in Table 1. Ninety-one of these patients had
Table 1 Baseline characteristics of 182 operated and non-operated patients with exocrine insufficiency caused by chronic pancreatitis and pancreatic cancer

\begin{tabular}{|c|c|c|}
\hline & $\begin{array}{l}\text { Operated } \\
\text { patients } N=91\end{array}$ & $\begin{array}{l}\text { Non-operated } \\
\text { patients } N=91\end{array}$ \\
\hline Age - median (IQR) & $60(49-68)$ & $57(50-67)$ \\
\hline Male sex $-n(\%)$ & $44(48)$ & $41(45)$ \\
\hline Chronic pancreatitis $-n(\%)$ & $54(59)$ & $83(91)$ \\
\hline Pancreatic cancer- $n(\%)$ & $37(41)$ & $8(9)$ \\
\hline $\begin{array}{l}\text { Supplementation duration- } \\
\text { median mo (IQR) }\end{array}$ & $54(28-131)$ & $60(49-68)$ \\
\hline
\end{tabular}

undergone pancreatic surgery $(84 \%$ underwent a resection procedure and $16 \%$ a drainage procedure; Table 2). The remaining 91 patients had not been operated upon.

The enzyme preparations used by the study population were all enteric coated and of porcine origin, Creon in $52 \%$ (Abbott, Solvay Pharma), Panzytrat in $32 \%$ (Tramedico, Aptalis Pharma), and Pancrease in $16 \%$ (Janssen-Cilag). Eighty-five percent used a high-dose preparation $(25,000$ FIP units of lipase). Twenty-four patients (26\%) took the enzymes before their meal, $62(68 \%)$ during a meal, and $11(12 \%)$ after a meal. Forty-nine patients (54\%) reported to take additional enzymes when they had a snack.

After surgery, the reported median enzyme dose was six capsules per day, and 23 patients $(25 \%)$ took three or less capsules per day (Table 3). There was no difference in dosing between the subgroups of patients who had undergone a pancreatic resection and a drainage procedure. Despite treatment, 62 cases $(68 \%)$ reported steatorrhea-related complaints, and 36 (39 \%) suffered from weight loss. From the patients who took three or less capsules per day, 16 $(70 \%)$ suffered from steatorrhea and $11(48 \%)$ from weight loss, versus $46(51 \%)$ and $23(34 \%)$ of the patients who used more than three capsules per day ( $p$ value 0.769 and

Table 2 Type of surgical procedure in the 91 operated patients with chronic pancreatitis and pancreatic cancer

\begin{tabular}{lcc}
\hline & $\begin{array}{l}\text { Chronic } \\
\text { pancreatitis } \\
N=54\end{array}$ & $\begin{array}{l}\text { Pancreatic } \\
\text { cancer } N=37\end{array}$ \\
\hline Type of surgical procedures & $20(37)$ & $31(84)$ \\
Whipple $-n(\%)$ & $5(9)$ & $3(8)$ \\
Distal pancreatectomy— $n(\%)$ & $14(26)$ & $1(3)$ \\
Pancreatic head resection- $n(\%)$ & - & $2(5)$ \\
Total pancreatectomy— $n(\%)$ & $8(15)$ & - \\
$\begin{array}{l}\text { Type of drainage procedures } \\
\text { Pancreaticojejunostomy- } n(\%)\end{array}$ & $7(13)$ & - \\
$\begin{array}{l}\text { Other drainage } \\
\text { procedures- } n(\%)\end{array}$ & & \\
\hline
\end{tabular}


Table 3 Treatment outcome of enzyme replacement therapy in 91 surgically treated patients with chronic pancreatitis and pancreatic cancer and 91 nonoperated patients

${ }^{\mathrm{a}}$ Number of enteric-coated capsules containing 25,000 FIP units of lipase

\begin{tabular}{|c|c|c|c|c|}
\hline & \multicolumn{3}{|c|}{ Operated patients } & \multirow{2}{*}{$\begin{array}{l}\text { Non-operated patients } \\
\text { All } N=91\end{array}$} \\
\hline & All $N=91$ & $\begin{array}{l}\text { Chronic pancreatitis } \\
N=54(59 \%)\end{array}$ & $\begin{array}{l}\text { Pancreatic cancer } \\
N=37(41 \%)\end{array}$ & \\
\hline $\begin{array}{l}\text { Enzyme dose/day }{ }^{\mathrm{a}} ; 25 \% \\
\text { of patients }\end{array}$ & $\leq 3$ & $\leq 4$ & $\leq 3$ & $\leq 3$ \\
\hline $50 \%$ of patients & $\leq 6$ & $\leq 6$ & $\leq 5$ & $\leq 4$ \\
\hline $75 \%$ of patients & $\leq 8$ & $\leq 8$ & $\leq 7$ & $\leq 6$ \\
\hline $\begin{array}{l}\text { Symptoms of } \\
\text { steatorrhea- } n(\%)\end{array}$ & $62(68)$ & $37(69)$ & $25(68)$ & $61(67)$ \\
\hline Weight loss $-n(\%)$ & $36(39)$ & $19(35)$ & $17(46)$ & $35(39)$ \\
\hline Fat restriction- $n(\%)$ & $44(48)$ & $28(52)$ & $16(43)$ & $52(57)$ \\
\hline Referral to dietician- $n(\%)$ & $33(36)$ & $14(26)$ & $19(51)$ & $21(23)$ \\
\hline
\end{tabular}

0.219 , respectively). Only 33 patients (36\%) reported to have visited a dietician for their exocrine insufficiency, and 44 patients (48\%) kept an unnecessary dietary fat restriction, either prescribed by a physician or dietician, or selfimposed. All these results were comparable to the results of the non-operated patients.

\section{Discussion}

This study is the first to capture how postoperative patients with exocrine insufficiency are being treated and gives an insight in the clinical practice of pancreatic enzyme supplementation. The results imply that, even in countries with a well-organized health care system, the majority of patients are undertreated.

Although steatorrhea-related symptoms may correlate poorly with the objective measure of steatorrhea, we believe we have gathered some valid data. Despite enzyme replacement, most patients were still bothered by steatorrhearelated complaints, although studies have shown that adequate enzyme therapy can relieve these symptoms completely. Furthermore, guidelines stress that with the proper amount of enzymes, patients should be able to maintain a normal diet. In our study population, most patients were not aware of this and tended to avoid fat. Interestingly, results were equally poor for non-operated patients.

Apparently, surgeons as well as gastroenterologists fail to achieve a satisfactory treatment response in many of their patients. This poor outcome may be explained by the particular intricacies of pancreatic enzyme replacement therapy. The enzyme dose needs to be individually adjusted based on the residual pancreatic function and the dietary fat intake. $^{20-27}$ In addition, after surgery, the altered anatomy should be taken into account. This variability in individual dosage response and the lack of practice guidelines make it difficult for physicians to prescribe the proper dose. Also, publications on this subject are scarce, and therefore, physicians are not well informed.

Furthermore, besides theoretical knowledge, effective treatment requires ample diligence of the treating physician to train patients in flexible dosing. However, enzyme supplementation may not seem a major concern in patients with chronic pancreatitis who are treated for severe pain. Moreover, in case of a life-threatening condition such as pancreatic cancer, treatment of exocrine insufficiency may seem futile. Yet, even in these patients, steatorrhea-related symptoms and associated weight loss can be a tremendous burden. A randomized trial by Bruno et al. proved that treatment of exocrine insufficiency is beneficial in such patients. Twenty-one patients with exocrine insufficiency were treated for 8 weeks with either six capsules of a high-dose pancreatic enzyme preparation per day, or a placebo. ${ }^{16}$ All patients received dietary consultation. A significant difference in body weight was observed; patients on pancreatic enzymes gained $1.2 \%(0.7 \mathrm{~kg})$, whereas patients on placebo lost $3.7 \%(2.2 \mathrm{~kg})$. In addition, the fat absorption coefficient in patients on pancreatic enzymes improved by $12 \%$, whereas in placebo patients, it dropped by $8 \%$. Also, guidelines published in Gut have recommended that pancreatic enzymes should be used in exocrine-insufficient patients with pancreatic cancer to maintain weight and increase their quality of life. ${ }^{28}$

The anatomical changes resulting from pancreatic surgery require careful consideration in the diagnosis and treatment of maldigestion. ${ }^{29}$ First of all, the extent of the pancreatic resection is an important denominator for the development of exocrine insufficiency. In addition, the normal digestive physiology is altered in case of reconstructive surgery after a Whipple's procedure. This may lead to a reduction in exocrine pancreatic secretion due to abnormal postprandial CCK release. Also, asynchrony between gastric emptying and pancreatic secretion in the small intestinal lumen may develop, resulting in improper mixing of enzymes and chyme, a phenomenon called secondary 
exocrine insufficiency. ${ }^{30}$ Furthermore, changes in gastric and duodenal acidity may influence the denaturation of enzymes and the dissolution of enteric-coated mini-dose units. Finally, after surgery, in particular after a Roux-en-Y anastomosis or pancreaticoduodenectomy, malabsorption may develop due to bacterial overgrowth.

Although studies have shown different gastric-emptying profiles after conventional and pylorus-preserving pancreaticoduodenectomy, long-term results have shown that enzyme replacement therapy with enteric-coated preparations is effective postsurgically. ${ }^{31-33}$ Therefore, the pancreatic function should be evaluated postoperatively. A fecal Elastase-1 test should be routinely performed, also in asymptomatic patients, because clinical signs of steatorrhea may be absent as patients tend to limit fat intake to reduce symptoms. Pancreatic enzyme supplementation should be considered in every patient with proven exocrine insufficiency, irrespective of the underlying disease or prognosis. Even in the case of asymptomatic exocrine insufficiency, treatment is indicated because studies have shown that malnutrition may develop in these patients. Moreover, enzymes can also be effective in patients with clinical signs of malabsorption without proven exocrine insufficiency because secondary exocrine insufficiency may be present.

There are very few studies that address how pancreatic enzyme replacement therapy should be dosed. Only one randomized trial has compared the efficacy of a fixed enzyme dosage to self-administration ad libitum according to fat intake in exocrine insufficient patients with chronic pancreatitis. ${ }^{34}$ There was a significant increase from 5 capsules per day during the fixed treatment period to 11 capsules per day during the self-administration period. With this increased dose, a significant decrease in steatorrhea-related symptoms was observed. The authors concluded that efficacy is higher when enzymes are self-dosed by patients in a flexible manner.

Despite the absence of an easy method to establish the adequate dose of pancreatic enzymes, some guidelines can be given. A reasonable starting dose is 50,000 to 75,000 units of lipase for a main meal and 25,000 units for snacks. Subsequently, patients should be instructed to vary the dose according to their dietary fat intake, up to a maximum of 16 capsules a day. They should be explained that the presence of steatorrhea-related symptoms and weight loss imply an insufficient dose of enzymes that needs to be increased. The timing of the capsule ingestion is also important because the enzymes have to be mixed with the chyme to be effective. Patients should be instructed to take the enzymes during or right after a meal. ${ }^{20,35-38}$ Finally, management of exocrine insufficiency can be greatly facilitated by dietary counseling from a well-trained, specialized dietician. A dietician can teach patients the principles of flexible dosing and prevent them from keeping unnecessary dietary restrictions because many patients tend to avoid fat out of fear for steatorrhea-related complaints.
When treatment response remains unsatisfactorily despite optimal use of enzymes, other steps may be needed. To improve therapeutic efficacy, inhibition of gastric secretion (if gastric acid secretion is preserved) can be attempted by the administration of a proton pump inhibitor. Also, capsules can be opened prior to ingestion, or uncoated enzyme preparations can be prescribed, as accelerated gastric emptying may prevent timely dissolution. If the patient still does not have a satisfactory treatment response, testing for bacterial overgrowth and celiac disease should be considered.

Our study was bound to certain limitations. First of all, due to the design as an anonymous survey, which was required by the medical ethical committee, certain information about the patient population was unavailable. Therefore, we were unable to calculate the response rate, to provide information about the lifestyle of patients, and the etiology and severity of the pancreatitis or pancreatic cancer. Furthermore, data could not be objectified in case of remaining questions or uncertainties. For example, the outcome measure of weight loss could have been influenced by other factors, such as the underlying malignancy. Finally, a selection bias might have occurred. After all, this survey was distributed among members of a patient organization, who are generally highly motivated and better informed. Also, complex pancreatic surgery is mainly executed in tertiary referral centers, where treating physicians are likely to be more experienced in diagnosing and treating exocrine insufficiency. However, if this would be the case, it only stresses our conclusions as results elsewhere are expected to be even worse.

\section{Conclusion}

This is the first study to give insight in the daily practice of pancreatic enzyme usage in patients with exocrine insufficiency after pancreatic surgery. Our results indicate that a substantial proportion of patients are underdosed and that there is ample room for improvement. To accomplish this, physicians should be attentive on treating exocrine insufficiency, also in patients with an unfavorable prognosis. Patients should be better educated in using pancreatic enzymes in a flexible manner, depending on their meal composition. For this, involvement of a well-trained, specialized dietician is desirable.

Conflict of interest Mrs. E.C.M. Sikkens has received an unrestricted research grant from "Aptalis Pharma Inc., Canada."

Open Access This article is distributed under the terms of the Creative Commons Attribution License which permits any use, distribution, and reproduction in any medium, provided the original author(s) and the source are credited. 


\section{Appendix: Patient Survey; Questions Regarding Enzyme Replacement Therapy, Symptoms, and Referral \\ to a Dietician}

Question 1

Have you ever been diagnosed with:

Chronic pancreatitis

(a chronic or recurrent inflammation of the pancreas)

Pancreatic cancer

(also called pancreatic carcinoma or malignancy)

\section{Question 2}

Have you ever undergone pancreatic surgery $\quad$ yes / no

If yes:

Type of operation:

\section{Question 3}

Are you using pancreatic enzyme preparations because your own pancreas does

yes / no not produce enough pancreatic enzymes

\section{Question 4}

Since when have you been using pancreatic enzyme capsules (please give month and year)?

\section{Question 5}

How many pancreatic enzyme-replacing capsules are you currently using per day?

\section{Question 6}

When do you generally take the enzyme-replacement medication:

(please check all applicable boxes, multiple answers are possible if the dosage was spread out over a meal)

Before a meal

During a meal

After a meal

\section{Question 7}

What brand of capsules do you use (check all applicable boxes)

$$
\begin{aligned}
& \text { Creon "Forte" } \\
& \text { Creon "Fot "LD" } \\
& \text { Panzytrat "LD" } \\
& \text { Panzytrat "HL" } \\
& \text { Pancrease } \\
& \text { Other, namely }
\end{aligned}
$$

\section{Question 8}

Do you keep dietary restrictions, and if so, what kind?

\section{Question 9}

Do you currently have symptoms of:

Fatty diarrhea (frequent, voluminous stools that are difficult to flush and stick to the toilet bowl) yes / no

Stomach cramps and/or bloating

Weight loss

\section{Question 10}

Has a dietician ever been involved, to explain about how you should use pancreatic enzymes

\section{Question 11}

\section{References}

1. Lankisch PG, Lembcke B, Wemken G, Creutzfeldt W: Functional reserve capacity of the exocrine pancreas. Digestion 1986;35:175-181.
2. Layer P, Go VL, DiMagno EP: Fate of pancreatic enzymes during small intestinal aboral transit in humans. Am J Physiol 1986;251:G475-480.

3. Tran TC, van't Hof G, Kazemier G, Hop WC, Pek C, van Toorenenbergen AW, van Dekken H, van Eijck CH: Pancreatic 
fibrosis correlates with exocrine pancreatic insufficiency after pancreatoduodenectomy. Dig Surg 2008;25:311-318.

4. Bruno MJ: Maldigestion and exocrine pancreatic insufficiency after pancreatic resection for malignant disease: Pathofysiology and treatment. Pancreatology 2001;1:55-61.

5. Cahen DL, Gouma DJ, Nio Y, Rauws EA, Boermeester MA, Busch OR, Stoker J, Lameris JS, Dijkgraaf MG, Huibregtse $\mathrm{K}$, Bruno MJ: Endoscopic versus surgical drainage of the pancreatic duct in chronic pancreatitis. $N$ Engl J Med 2007;356:676-684.

6. Riediger H, Adam U, Fischer E, Keck T, Pfeffer F, Hopt UT, Makowiec F: Long-term outcome after resection for chronic pancreatitis in 224 patients. J Gastrointest Surg 2007;11:949-959; discussion 959-960.

7. Kato H, Nakao A, Kishimoto W, Nonami T, Harada A, Hayakawa T, Takagi H: 13c-labeled trioctanoin breath test for exocrine pancreatic function test in patients after pancreatoduodenectomy. Am J Gastroenterol 1993;88:64-69.

8. Pasquali C, Fogar P, Sperti C, Basso D, De Paoli M, Plebani M, Pedrazzoli S: Efficacy of a pancreatic enzyme formulation in the treatment of steatorrhea in patients with chronic pancreatitis. Current Therapeutic Research - Clinical and Experimental 1996;57:358-365.

9. Rivers JP, Hassam AG: Defective essential-fatty-acid metabolism in cystic fibrosis. Lancet 1975;2:642-643.

10. Roberts IM: Enzyme therapy for malabsorption in exocrine pancreatic insufficiency. Pancreas 1989;4:496-503.

11. Rosenlund ML, Kim HK, Kritchevsky D: Essential fatty acids in cystic fibrosis. Nature 1974;251:719.

12. Dutta SK, Bustin MP, Russell RM, Costa BS: Deficiency of fatsoluble vitamins in treated patients with pancreatic insufficiency. Ann Intern Med 1982;97:549-552.

13. Kalivianakis M, Minich DM, Bijleveld CM, van Aalderen WM, Stellaard F, Laseur M, Vonk RJ, Verkade HJ: Fat malabsorption in cystic fibrosis patients receiving enzyme replacement therapy is due to impaired intestinal uptake of long-chain fatty acids. Am J Clin Nutr 1999;69:127-134.

14. Lankisch PG, Lembcke B, Goke B, Creutzfeldt W: Therapy of pancreatogenic steatorrhoea: Does acid protection of pancreatic enzymes offer any advantage? Z Gastroenterol 1986;24:753-757.

15. Sikkens EC, Cahen DL, Kuipers EJ, Bruno MJ: Pancreatic enzyme replacement therapy in chronic pancreatitis. Best Pract Res Clin Gastroenterol 2010;24:337-347.

16. Bruno MJ, Haverkort EB, Tijssen GP, Tytgat GN, van Leeuwen DJ: Placebo controlled trial of enteric coated pancreatin microsphere treatment in patients with unresectable cancer of the pancreatic head region. Gut 1998;42:92-96.

17. Gullo L, Stella A, Labriola E, Costa PL, Descovich G, Labo G: Cardiovascular lesions in chronic pancreatitis: A prospective study. Dig Dis Sci 1982;27:716-722.

18. Gullo L, Tassoni U, Mazzoni G, Stefanini F: Increased prevalence of aortic calcification in chronic pancreatitis. Am J Gastroenterol 1996;91:759-761.

19. Mundlos S, Kuhnelt P, Adler G: Monitoring enzyme replacement treatment in exocrine pancreatic insufficiency using the cholesteryl octanoate breath test. Gut 1990;31:1324-1328.

20. DiMagno EP, Malagelada JR, Go VL, Moertel CG: Fate of orally ingested enzymes in pancreatic insufficiency. Comparison of two dosage schedules. N Engl J Med 1977;296:13181322 .

21. Keller J, Runzi M, Goebell H, Layer P: Duodenal and ileal nutrient deliveries regulate human intestinal motor and pancreatic responses to a meal. Am J Physiol 1997;272:G632637.
22. Layer P, Peschel S, Schlesinger T, Goebell H: Human pancreatic secretion and intestinal motility: Effects of ileal nutrient perfusion. Am J Physiol 1990;258:G196-201.

23. Layer P, Schlesinger T, Groger G, Goebell H: Modulation of human periodic interdigestive gastrointestinal motor and pancreatic function by the ileum. Pancreas 1993;8:426-432.

24. Layer P, von der Ohe MR, Holst JJ, Jansen JB, Grandt D, Holtmann G, Goebell H: Altered postprandial motility in chronic pancreatitis: Role of malabsorption. Gastroenterology 1997;112: 1624-1634.

25. Read NW, McFarlane A, Kinsman RI, Bates TE, Blackhall NW, Farrar GB, Hall JC, Moss G, Morris AP, O'Neill B, et al.: Effect of infusion of nutrient solutions into the ileum on gastrointestinal transit and plasma levels of neurotensin and enteroglucagon. Gastroenterology 1984;86:274-280.

26. Rosa ESL, Troncon LE, Gallo L, Jr., Foss MC, Passos AD, Perdona GC, Achcar JA, Oliveira RB (2010) Determinants of accelerated small intestinal transit in alcohol-related chronic pancreatitis. Dig Dis Sci 55(4):1017-25

27. Zentler-Munro PL, Fitzpatrick WJ, Batten JC, Northfield TC: Effect of intrajejunal acidity on aqueous phase bile acid and lipid concentrations in pancreatic steatorrhoea due to cystic fibrosis. Gut 1984;25:500-507.

28. Guidelines for the management of patients with pancreatic cancer periampullary and ampullary carcinomas. Gut 2005;54 Suppl 5: v1-16.

29. Dominguez-Munoz JE: Pancreatic enzyme replacement therapy: Exocrine pancreatic insufficiency after gastrointestinal surgery. HPB (Oxford) 2009;11 Suppl 3:3-6.

30. Ito K: Duodenum preservation in pancreatic head resection to maintain pancreatic exocrine function (determined by pancreatic function diagnostant test and cholecystokinin secretion). J Hepatobiliary Pancreat Surg 2005;12:123-128.

31. Braga M, Cristallo M, De Franchis R, Mangiagalli A, Zerbi A, Agape D, Primignani M, Di Carlo V: Pancreatic enzyme replacement therapy in post-pancreatectomy patients. Int J Pancreatol 1989;5 Suppl:37-44.

32. Barreiro-de Acosta M, Lorenzo A, Dominguez-Munoz JE: Adalimumab in ulcerative colitis: Two cases of mucosal healing and clinical response at two years. World J Gastroenterol 2009;15:3814-3816.

33. Bruno MJ, Borm JJ, Hoek FJ, Delzenne B, Hofmann AF, de Goeij JJ, van Royen EA, van Gulik TM, de Wit LT, Gouma DJ, van Leeuwen DJ, Tytgat GN: Comparative effects of entericcoated pancreatin microsphere therapy after conventional and pylorus-preserving pancreatoduodenectomy. Br J Surg 1997;84:952956.

34. Ramo OJ, Puolakkainen PA, Seppala K, Schroder TM: Selfadministration of enzyme substitution in the treatment of exocrine pancreatic insufficiency. Scand J Gastroenterol 1989;24:688-692.

35. Dominguez-Munoz JE, Iglesias-Garcia J, Iglesias-Rey M, Figueiras A, Vilarino-Insua M: Effect of the administration schedule on the therapeutic efficacy of oral pancreatic enzyme supplements in patients with exocrine pancreatic insufficiency: A randomized, three-way crossover study. Aliment Pharmacol Ther 2005;21:993-1000.

36. Keller J, Layer P: Pancreatic enzyme supplementation therapy. Curr Treat Options Gastroenterol 2003;6:369-374.

37. Keller J, Layer P: Human pancreatic exocrine response to nutrients in health and disease. Gut 2005;54 Suppl 6:vi1-28.

38. Layer P, Yamamoto H, Kalthoff L, Clain JE, Bakken LJ, DiMagno EP: The different courses of early- and late-onset idiopathic and alcoholic chronic pancreatitis. Gastroenterology 1994;107:14811487. 